\title{
Effect of tillage system on yield and weed populations of soybean (Glycin Max L.)
}

\author{
SEYED Z. HOSSEINI ${ }^{1}$, SAEED FIROUZI ${ }^{2}$, HASHEM AMINPANAH ${ }^{2}$ and HAMID R. SADEGHNEJHAD ${ }^{3}$ \\ ${ }^{1}$ Department of Agronomy, Guilan Science and Research Branch, Islamic Azad University, Rasht, 4293974789, Iran \\ ${ }^{2}$ Department of Agronomy and Plant Breeding, Rasht Branch, Islamic Azad University, Rasht, 4147654919, Iran \\ ${ }^{3}$ Department of Agricultural Engineering, Agricultural and Natural Resources \\ Research Center of Golestan Province, Gorgan, 4915677555, Iran
}

Manuscript received on December 2, 2014; accepted for publication on January 27, 2015

\begin{abstract}
Field experiment was conducted at Agricultural and Natural Resources Research Center of Golestan Province, Iran, to determine the effects of tillage system and weed management regime on yield and weed populations in soybean (Glycin max L.). The experimental design was a split plot where the whole plot portion was a randomized complete block with three replicates. Main plots were tillage system: 1- Notill row crop seeding, 2- No-till seed drilling, 3- Tillage with disc harrow and drill planting, 4- Tillage with chisel packer and drill planting. The subplots were weed management regimes: 1-Weed control with herbicide application, 2- Hand weeding, 3-Herbicide application plus hand weeding, and 4- Non-weeding. Results indicated that the main effects of tillage system and weed management regime were significant for seed yield, pod number per plant, seed number per pod, weed density and biomass, while their interaction were significant only for weed density, weed biomass, and seed number per pod. The highest grain yields $\left(3838 \mathrm{~kg} \mathrm{ha}^{-1}\right)$ were recorded for No-till row crop seeding. The highest seed yield $\left(3877 \mathrm{~kg} \mathrm{ha}^{-1}\right)$ also was recorded for weed control with herbicide and hand weeding treatment, followed by hand weeding (3379 $\left.\mathrm{kg} \mathrm{ha}^{-1}\right)$.
\end{abstract}

Key words: soybean, tillage systems, weed management regimes, yield, yield components.

\section{INTRODUCTION}

Soybean is the most important edible oil-bearing crop in the world and it grows in tropical, subtropical, and temperate climates. It consists of more than $36 \%$ protein, $30 \%$ carbohydrates, $20 \%$ oil, and considerable amounts of dietary fiber, mineral nutrients and vitamins. In addition, biological nitrogen fixation in the soybeanbradyrhizobia symbiosis improves soil fertility.

Correspondence to: Saeed Firouzi

E-mail: firoozi@iaurasht.ac.ir
The U.S., Argentina, Brazil, China and India are the world's largest soybean producers and represent more than $90 \%$ of global soybean production. Approximately 209,000 tons of soybeans were harvested from 115,000 hectares of cropland in Iran in 2010 (FAO 2010). Golestan province ranks as the first soybean producer in Iran, accounting for over $75 \%$ of total soybean production (Anonymous 2010). In this province, soybean is planted either in early May and harvested in late July or is planted after wheat harvesting as double cropping in late August and harvested in early November. 
Tillage is the mechanical manipulation of the soil and plant residues to prepare an appropriate seedbed for crop planting, which have several advantages such as loosening soil, regulating the circulation of water and air within the soil, increasing the release of nutrient elements from the soil for crop growth, and controlling weeds by burying weed seeds and emerged seedlings (Reicosky and Allmaras 2003). However, intensive tillage practices may affect the soil structure, soil porosity, storage of water in soil, aggregate stability, soil erosion, soil organic matter, soil micro- and macro-fauna, environmental quality by accelerating greenhouse gas emissions, and production costs. Such concerns have led to the search for tillage systems that minimize negative impacts to the environment while sustaining economic crop productivity. Conservation tillage techniques, including minimum tillage and notillage, minimize the impact on soil structure and on soil biota (Cassiolato et al. 2001, Cook 2006), and may help reduce $\mathrm{CO} 2$ emissions in comparison to traditional tillage (Hernanz et al. 2009). To address these concerns, conservation tillage systems need to be adopted and implemented in crop production systems. The Conservation Technology Information Center (CTIC) defines conservation tillage as any tillage and planting system that leaves at least 30 percent of the soil surface covered with crop residue after planting (CTIC 1998). No-tillage maintains more crop residue on soil surface but might not allow profitable production if herbicides fail or a uniform plant stand is not established. It was found that corn yield was not reduced under the zonetillage compared with the conventional moldboard plow system (D.C. Hooker, unpublished data).

Germination of many seeds is enhanced by soil disturbance (Cavers and Benoit 1989), likely due to seed exposure to light, improved soil aeration, increased loss of volatile inhibitors from soil, and movement of seeds to more favorable germination sites (Egley 1986). However, germination of some seeds is not promoted by soil disturbance. Moreover, the type, depth, and frequency of soil disturbance are important for the fate of weed. In addition, increased plant residues on soil surface may contribute to control invasive plants since they exert a suppressive effect on the seed germination and growth of these plants.

In recent years, an increasing number of soybean farmers have adopted conservation tillage practices. The development of better herbicide applications has allowed producers to use less intensive soil cultivation practices. The objective of this research was to determine the effects of some tillage systems and weed management regimes on yield and yield components of soybean production in the Gorgan Province of Iran.

\section{MATERIALS AND METHODS}

\section{EXPERIMENTAL SITE AND DESIGN}

Field experiment was conducted at the Crop Research Station of Gorgan, Iran, $\left(36^{\circ} 54^{\prime} \mathrm{N}, 54^{\circ}\right.$ $\left.20^{\prime} \mathrm{E}\right)$. Soil properties are presented in Table I. The experimental design was a split plot where the whole plot portion was a randomized complete block with three replicates. Main plots were tillage system: 1-No-till row crop seeding- NTRCS, 2No-till seed drilling- NTSD, 3- Tillage or land preparation with disc harrow and drill plantingTDHDP, 4- Tillage or land preparation with chisel packer and drill planting- TCPDP. The subplots were weed management regimes: 1- weed control with herbicide- $\mathrm{WCH}, 2$-weed control by hand weeding- WCHW, 3- weed control with herbicide application and hand weeding- $\mathrm{WCH}+\mathrm{WCHW}$, and 4- not weeded throughout the growing season- NW. Each main plot was $30 \times 5 \mathrm{~m}$ and a subplot was 7.5 $\times 5 \mathrm{~m}$. Soybean seeds (Glycin max L. var. DPX) were sown in September of 2012 at the density of 20 seeds $\mathrm{m}^{-2}$ in rows spaced $50 \mathrm{~cm}$ apart. Nitrogen (25 kg ha-1 of urea), Phosphorous $\left(25 \mathrm{~kg} \mathrm{ha}^{-1}\right.$ of triple superphosphate), and Potassium (50 kg ha- 
of potassium sulfate) were applied as a basal dose prior to sowing.

\section{DATA COLLECTION AND ANALYSIS}

At maturity stage, grain was harvested from a $2 \mathrm{~m}$ $\times 4 \mathrm{~m}$ area for each plot. Yield was expressed at $130 \mathrm{~g} \mathrm{~kg}^{-1}$ moisture. Pod number per plant and seed number per pod were determined on 10 randomly selected plants, avoiding borders, from each plot.
Seed weight (gram per 100 seed) was determined by counting 500 seeds from each yield sample, drying the seeds for 3 days to constant weight at $60{ }^{\circ} \mathrm{C}$ in an oven, weighing the sample, and then dividing the weight by five.

Weed density and biomass in each plot were determined from four $0.5 \mathrm{~m} \times 0.5 \mathrm{~m}$ quadrates at maturity stage, dried at $70{ }^{\circ} \mathrm{C}$ for 3 days and weighed.

TABLE I

Soil properties (0-30 cm depth) at Crop Research Station of Gorgan before soybean planting.

\begin{tabular}{cccccccc}
\hline OC $(\%)$ & $\mathrm{pH}$ & Sand $(\%)$ & Silt $(\%)$ & Clay $(\%)$ & Total N $(\%)$ & $\mathrm{P}\left(\mathrm{mg} \mathrm{kg}^{-1}\right)$ & $\mathrm{K}\left(\mathrm{mg} \mathrm{kg}^{-1}\right)$ \\
\hline 1.6 & 6.9 & 18 & 49 & 33 & 0.202 & 9 & 133 \\
\hline
\end{tabular}

The SAS statistical package version 9.1.3 (SAS Institute INC, Cary, NC) was used for data analyses (SAS 2004). Statistical analyses were performed using Analysis of Variance (ANOVA) for split-plot design to study the main and interaction effects. Where the F-ratios were found to be significant, treatment means were separated using the Fisher's least significant difference (LSD) at $5 \%$ level of probability. Pearson correlation coefficients were calculated using correlation analysis to assess the interrelationships between the different measured parameters.

\section{RESULTS AND DISCUSSION}

\section{SEED YIELD}

Main effects of tillage system (T) and weed management regime $(\mathrm{W})$ were significant for seed yield, while the $\mathrm{T} \times \mathrm{W}$ interaction was not significant (Table II). Regardless of weed management regime, the greatest grain yields were recorded for NTRCS (3838 kg ha ${ }^{-1}$ ) and NTSD (3574 kg $\left.\mathrm{ha}^{-1}\right)$, while the lowest amounts were recorded for TDHDP (3137 kg ha-1) and TCPDP (3080 kg ha-1) (Table III). This result is in accordance with the findings of Di Ciocco et al. (2008), who reported higher soybean seed yield for no tillage system compared with conventional tillage system. The increase in seed yield with NT management may be due to improved soil structure and surface residue cover which enhance water infiltration and root growth and/or reduce water losses through evaporation from the soil (Diaz-Zorita et al. 2004, Tarkalson et al. 2006). In contrast, Barrios et al. (2006) observed significantly higher yields in soybean crops under conventional tillage than in no tillage system in a rotation maize/soybean. At the same time, Lança Rodrígues et al. (2009) found no significant differences in soybean seed yields among tillage systems. Moreover, some studies have suggested that NT can lead to reduced yields because of lower $\mathrm{N}$ availability (Matowo et al. 1997) and greater nematode infestation (Koenning et al. 1995) compared with conventional tillage system. The greatest seed yield was recorded for weed control with herbicide + hand weeding (3877 $\mathrm{kg} \mathrm{ha}^{-1}$ ), followed by hand weeding (3379 $\left.\mathrm{kg} \mathrm{ha}^{-1}\right)$ and herbicide control (3359 $\left.\mathrm{kg} \mathrm{ha}^{-1}\right)$ and lastly by non-weeded treatment $\left(3015 \mathrm{~kg} \mathrm{ha}^{-1}\right)$ as averaged across tillage systems (Table III). In other words, soybean seed yield was reduced by $22 \%$ in un-weeded treatment compared with the WCH+WCHW treatment. Marangoni et al. (2013) reported that soybean seed yield was reduced by $30 \%$ due to weed competition. 
TABLE II

Mean squares of ANOVA for weed density (WD), weed biomass (WB), seed yield (SY), seed number per pod (SN), pod number per plant (PN) and seed weight (SW) as affected by tillage system and weed management regime.

\begin{tabular}{cccccccc}
\hline S.O.V & df & WD & WB & SY & PN & SN & SW \\
\hline R & 3 & $99^{\text {ns }}$ & $122^{\text {ns }}$ & $8417^{\text {ns }}$ & $66^{\text {ns }}$ & $23^{\text {ns }}$ & $16^{\text {ns }}$ \\
Tillage system (T) & 3 & $263^{* *}$ & $463^{* *}$ & $2096753^{* *}$ & $560^{* *}$ & $529^{* *}$ & $22^{\text {ns }}$ \\
Error (a) & 9 & 32 & 63 & 53145 & 43 & 15 & 18 \\
Weed management regime (W) & 3 & $3936^{* *}$ & $6936^{* *}$ & $2015901^{* *}$ & $2296^{* *}$ & $2346^{* *}$ & $15^{\text {ns }}$ \\
T×W & 9 & $179^{* *}$ & $290^{* *}$ & $48649^{\text {ns }}$ & $66^{\text {ns }}$ & $42^{*}$ & $2^{\text {ns }}$ \\
Error (b) & 36 & 38 & 54 & 56998 & 32 & 15 & 8 \\
CV (\%) & - & 19 & 20 & 7 & 9 & 9 & 8 \\
\hline
\end{tabular}

${ }^{*}$ and ${ }^{* *}$ represent significance at 0.05 and 0.01 probability levels, respectively.

${ }^{\mathrm{ns}}$ represents non-significance.

\section{POD NUMBER PER PLANT (PN)}

The main effects of tillage system (T) and weed management regime (W) on pod number per plant were significant at 0.01 probability level, while $\mathrm{T} \times \mathrm{W}$ interaction was not significant (Table II). Pod number per plant was significantly greater for NTRCS than the other tillage systems (Table III). The greatest pod number per plant was observed when weeds were controlled by herbicide and manually (WCH+WCHW). In contrast, the lowest pod number per plant was recorded for non-weeded plot. Pod number per plant was reduced by $40 \%$ in un-weeded plots compared with the $\mathrm{WCH}+\mathrm{WCHW}$ plots. Lança Rodrígues et al. (2009) reported that conventional and reduced tillage systems showed higher average values for pod number per plant, than no tillage systems. Mohammadi and Amiri (2011) also reported that number of pods per soybean plant was reduced by $60 \%$ due to full season weed interference. The same authors also found that the number of pod per plant was more sensitive to weed competition compared to the other yield components (e.g. seed number per pod and seed weight).

TABLE III

Seed yield (SY) and pod number per plant (PN) response to tillage system and weed management regime.

\begin{tabular}{lcc}
\hline \multicolumn{1}{c}{ Traits } & SY $\left(\mathrm{kg} \mathrm{ha}^{-1}\right)$ & PN \\
\hline Tillage system & $3838^{\mathrm{a}}$ & $66.06^{\mathrm{a}}$ \\
No-till row crop seeding & $3574^{\mathrm{a}}$ & $56.94^{\mathrm{b}}$ \\
No-till seed drilling & $3137^{\mathrm{b}}$ & $57.19^{\mathrm{b}}$ \\
Tillage with disc harrow and drill planting & $3080^{\mathrm{b}}$ & $51.81^{\mathrm{b}}$ \\
Tillage with chisel packer and drill planting & & \\
Weed management regime & $3359^{\mathrm{b}}$ & $60.19^{\mathrm{b}}$ \\
Weed control with herbicide & $3379^{\mathrm{b}}$ & $59.75^{\mathrm{b}}$ \\
Weed control by hand weeding & $3877^{\mathrm{a}}$ & $70.44^{\mathrm{a}}$ \\
Weed control with herbicide + hand weeding & $3015^{\mathrm{c}}$ & $41.63^{\mathrm{c}}$ \\
\hline Non-weeded throughout the growing season & &
\end{tabular}

Means within a column followed by the same letter are not significantly different at the 5\% level according to Fischer's Protected LSD test. 
SEED NUMBER PER POD (SN)

Tillage system $(\mathrm{T})$ and weed management regime $(\mathrm{W})$ and $\mathrm{T} \times \mathrm{W}$ interaction effects on seed number per pod were significant at 0.01 probability level. No significant difference in seed number per pod was observed between $\mathrm{WCH}$ and $\mathrm{WCH}+\mathrm{WCHW}$ treatments for TCPDP tillage system (Fig. 1). For other tillage systems, however, significant difference in seed number per pod was observed between $\mathrm{WCH}$ and $\mathrm{WCH}+\mathrm{WCHW}$ treatments (Fig.
1). Moreover, for all tillage systems, the highest and the lowest seed number per plant were observed for $\mathrm{WCH}+\mathrm{WCHW}$ and NW treatments, respectively (Fig. 1). Lança Rodrígues et al. (2009) found higher values for seed number per pod under conventional and reduced tillage systems than under no tillage system. Mohammadi and Amiri (2011) reported that seed number per pod was significantly lower in non-weeded plots compared to full-season weedfree plots.

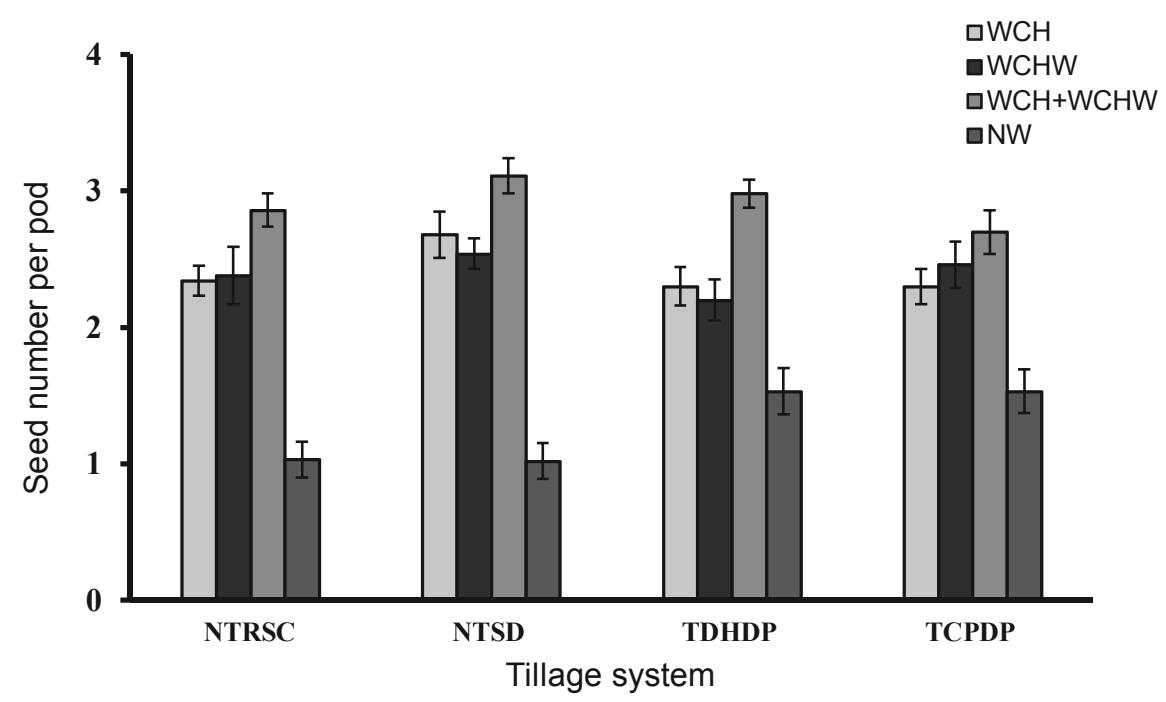

Figure 1 - Tillage system $\times$ weed management regime interaction effect on seed number per pod ((NTRCS, no-till row crop seeding; NTSD, no-till seed drilling; TDHDP, tillage with disc harrow and drill planting; TCPDP, tillage with chisel packer and drill planting; $\mathrm{WCH}$, weed control with herbicide; WCHW, weed control by hand weeding; $\mathrm{WCH}+\mathrm{WCHW}$, weed control with herbicide application and hand weeding; NW, non-weeded throughout the growing season). Vertical bars represent \pm 1 SE of means.

\section{SEED WEIGHT (SW)}

There were no significant effects of tillage system and weed management regime on soybean seed weight (Table III). In other words, there were no significant differences in seed weight among tillage systems and weed management regimes. Contrary to this result, Lança Rodrígues et al. (2009) found that seed weight was significantly higher in conventional tillage and no tillage than in reduced tillage. Moreover, Silva et al. (2008) found a significant reduction in the seed weight of soybean when the crop suffers the competition from weeds, especially at higher weed infestation. Moreover, Mohammadi and Amiri (2011) reported that seed weight in soybean reduced by $25.9 \%$ due to weed competition.

WEED DENSITY AND WEED BIOMASS

Redroot pigweed (Amaranthus retroflexus), Jimson weed (Datura stramonium), common cocklebur 
(Xanthiumstrumarium), dyer'scroton(Chrozophora tinctoria), lamb's quarters (Chenopodium album), and common purslane (Portulaca oleracea) were the most abundant dicotyledonous species, whereas barnyardgrass (Echinochloa crus-galli) and yellow nutsedge (Cyperus esculentus) were the most abundant monocotyledonous species. Weed density and weed biomass were significantly influenced by tillage system and weed management regime at 0.01 probability level. Moreover, the interaction between tillage system and weed management regime were significant for both of them. For NTRSC and NTSD, the highest weed density was recorded for NW treatment, while the lowest one was recorded for $\mathrm{WCH}+\mathrm{WCHW}$ treatments (Fig. 2). For TDHDP and TCPDP, weed density was significantly higher for NW treatment than the other weed management treatments and there were no significant differences in weed density among $\mathrm{WCH}, \mathrm{WCHW}, \mathrm{WCH}+\mathrm{WCHW}$ treatments (Fig. 2). In un-weeded plots, weed biomass was significantly higher for NTRSC (1080.8 \pm 94.3 $\left.\mathrm{g} \mathrm{m}^{-2}\right)$ and NTSD $\left(1139.5 \pm 82.6 \mathrm{~g} \mathrm{~m}^{-2}\right)$ than for TDHDP (633.8 $\left.\pm 77.3 \mathrm{~g} \mathrm{~m}^{-2}\right)$ and TCPDP (727.9 $\left.\pm 88.7 \mathrm{~g} \mathrm{~m}^{-2}\right)$. For NTRSC and NTSD, the highest and the lowest weed biomasses were recorded for $\mathrm{NW}$ and $\mathrm{WCH}+\mathrm{WCHW}$ treatments, respectively (Fig. 3). For TDHDP and TCPDP, there were no significant differences in weed biomass among $\mathrm{WCH}, \mathrm{WCHW}, \mathrm{WCH}+\mathrm{WCHW}$ treatments; the highest weed biomass was recorded for NW treatment (Fig. 3).

It is well known that the implementation of different tillage systems have different effects on soil nutrients, soil structure and temperature, water conservation, soil $\mathrm{pH}$, and weed seed burial depth (Al-Kaisi et al. 2005), all of which may affect the germination and growth of certain weed species and lead to changes in weed density and weed composition (Carter and Ivany 2006, Sosnoskie et al. 2006).

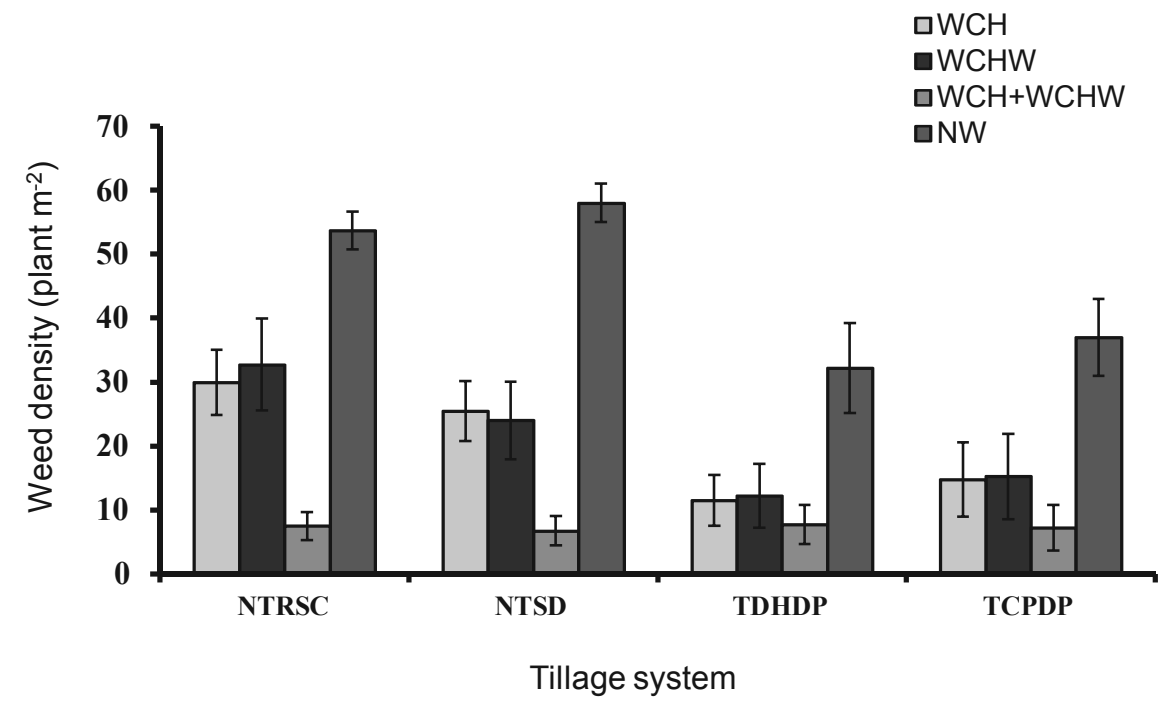

Figure 2 - Tillage system $\times$ weed management regime interaction effect on weed density (NTRCS, no-till row crop seeding; NTSD, no-till seed drilling; TDHDP, tillage with disc harrow and drill planting; TCPDP, tillage with chisel packer and drill planting; $\mathrm{WCH}$, weed control with herbicide; WCHW, weed control by hand weeding; $\mathrm{WCH}+\mathrm{WCHW}$, weed control with herbicide application and hand weeding; NW, non-weeded throughout the growing season). Vertical bars represent \pm 1 SE of means. 


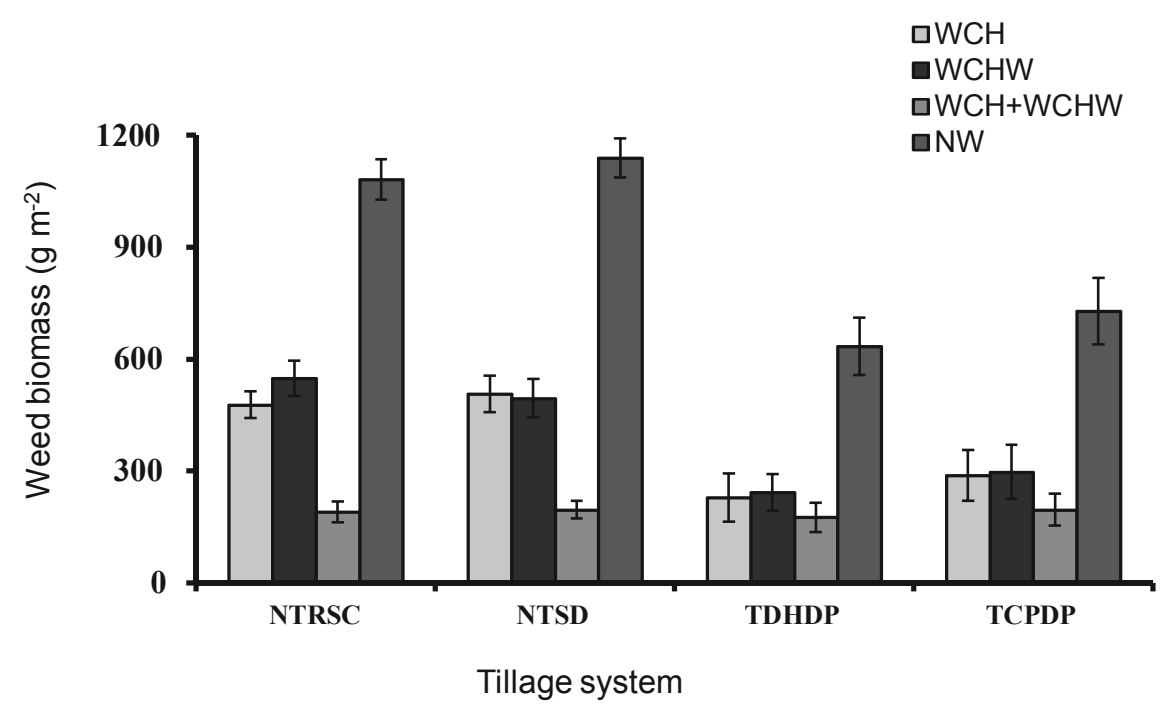

Figure 3 - Tillage system $\times$ weed management regime interaction effect on weed biomass per $\mathrm{m}^{2}$ (NTRCS, no-till row crop seeding; NTSD, no-till seed drilling; TDHDP, tillage with disc harrow and drill planting; TCPDP, tillage with chisel packer and drill planting, $\mathrm{WCH}$, weed control with herbicide; WCHW, weed control by hand weeding; WCH+WCHW, weed control with herbicide application and hand weeding; NW, non-weeded throughout the growing season). Vertical bars represent \pm 1 SE of means.

\section{CONCLUSIONS}

This experiment illustrated that soybean grain yield was significantly influenced by tillage system and weed management regime. Regardless of weed management regime, soybean grown under no-till row crop seeding and no-till seed drilling systems produced higher grain yield compared to those grown under tillage with disc harrow and drill planting or tillage with chisel packer and drill planting systems. The greatest seed yield was recorded for weed control with herbicide + hand weeding ( $\left.3877 \mathrm{~kg} \mathrm{ha}^{-1}\right)$, followed by hand weeding $\left(3379 \mathrm{~kg} \mathrm{ha}^{-1}\right)$ and herbicide control $(3359 \mathrm{~kg}$ $\mathrm{ha}^{-1}$ ) and lastly by non-weeded treatment (3015 $\mathrm{kg} \mathrm{ha}^{-1}$ ) as averaged across tillage system.

\section{ACKNOWLEDGMENTS}

The authors are grateful for the scientific support of Guilan Science and Research Branch, Islamic Azad University and for the technical assistance provided by the Agricultural and Natural Resources Research Center of Golestan Province, Iran.

\section{RESUMO}

O experimento foi conduzido no Centro de Pesquisa Agrícola e de Recursos Naturais da Província de Golestan, Irã, para determinar os efeitos do sistema de plantio direto e regime de manejo de plantas invasoras sobre as populações de plantas invasoras em cultivo de soja (Glycin max L.). O delineamento experimental foi em parcelas subdivididas, em blocos casualizados com três repetições. As parcelas principais foram nos seguintes sistema de plantio direto: 1- Semeadura direta em linha, 2- Plantio direto de sementeira, 3- Plantio direto com grade de disco e plantio em cova, 4- Plantio direto com cinzel e plantio em cova. As subparcelas foram dos seguintes regimes de controle de plantas invasoras: 1- Aplicação de herbicida, 2- Capina manual, 3- Aplicação de herbicida e capina manual, 4- Sem controle químico e sem capina manual. Os resultados indicaram que os principais efeitos do sistema de plantio direto e do regime de manejo de plantas daninhas foram significativos para a produção de sementes, número 
de vagens por planta, número de sementes por vagem, densidade e biomassa de plantas invasoras, enquanto as interações dos tratamentos foram significativas apenas para densidade de plantas invasoras, biomassa de plantas invasoras e número de sementes por vagem. As maiores produções de grãos $\left(3838 \mathrm{~kg} \mathrm{ha}^{-1}\right)$ foram registrados para semeadura direta em linha. O maior rendimento de sementes $\left(3877 \mathrm{~kg} \mathrm{ha}^{-1}\right)$ foi observado para o tratamento de controle de plantas invasoras com herbicidas e capina manual, seguido por capina manual (3379 $\left.\mathrm{kg} \mathrm{ha}^{-1}\right)$.

Palavras-chave: soja, sistemas de plantio direto, regimes de manejo de plantas invasoras, produção, componentes da produção.

\section{REFERENCES}

AL-KAISI MM, YIN X AND LICHT MA. 2005. Soil carbon and nitrogen changes as influenced by tillage and cropping systems in some Iowa soils. Agric Ecosyst Environ 105: 635-647.

ANONYMOUS. 2010. Agricultural Statistics Report. Vol. 1., Field Crops. Vol. 1. Statistics and IT Bureau. Jahad e Keshavarzi Ministry Publication, Tehran, Iran.

BARrios MB, BOZZO AA, DEBELIS SP, PEREYRA AM AND BUJAN A. 2006. Soil physical properties and root activity in a soybean second crop/maize rotation under direct sowing and conventional tillage. Span J Agric Res 4: 355362.

CARTER MR AND IVANY JA. 2006. Weed seed bank composition under three long-term tillage regimes on a fine sandy loam in Atlantic Canada. Soil Till Res 90: 2938.

CAssiolato AMR, VAlpassos MAR And Alves MC. 2001. Changes on a microbial activity and soil chemical properties due to different management systems. In: I World Congress on Conservation Agriculture, Madrid, Spain, p. 502-507.

CAVERS PB AND BENOIT DL. 1989. Seed banks in arable lands. In: Leck MA, Parker VT and Simpson RL (Eds), Ecology of soil seed banks. Academic Press, San Diego, USA, p. 309-328.

COOK RJ. 2006. Toward cropping systems that enhance productivity and sustainability. Proceeding Proc Natl Acad Sci USA 103(49): 18389-18394.

CTIC - CONSERVATION TILlAGE INFORMATION CENTER. 1998. National survey of conservation tillage practices. West Lafayette, IN: Conservation Tillage Information Center.

Di Ciocco C, Coviella C, PenON E, DiAZ-Zorita M AND LOPEZ S. 2008. Short communication. Biological fixation of nitrogen and $\mathrm{N}$ balance in soybean crops in the pampas region. Span J Agric Res 6: 114-119.

Diaz-Zorita M, Grove JH, Murdock L, Herbeck J AND PERFECT E. 2004. Soil structural disturbance effects on crop yields and soil properties in a no-till production system. Agron J 96: 1651-1659.

EGLEY GH. 1986. Stimulation of weed seed germination in soil. Rev Weed Sci 2: 67-89.

FAO - FOOD AND AGRICULTURAL ORGANIZATION. 2010. Www.fao.org.

HERNANZ JL, SÁNCHEZ-GIRÓN V AND NAVARRETE L. 2009. Soil carbon sequestration and stratification in a cereal/ leguminous crop rotation with three tillage systems in semiarid conditions. Agric Ecosyst Environ 133(1-2): 114122.

KOENNING SR, SCHMITT DP, BARKER KR AND GUMPERTZ ML. 1995. Impact of crop rotation and tillage system on Heterodera glycines population density and soybean yield. Plant Dis 79: 282-286.

LANÇA RODRÍGUES JG, GAMERO CA, COSTA FERNANDES J AND MIRÁS-AVALOS JM. 2009. Effects of different soil tillage systems and coverage on soybean crop in the Botucatu Region in Brazil. Span J Agric Res 7(1): 173180.

MARANGONi RE, JAKELAITIS A, TAVARES CJ, REZENDE BPM, MELlo FILHO OL AND CUNHA PCR. 2013. Effect of weed interference on soybean cultivars at two sowing times. Planta Daninha 31(3): 511-519.

MATOWO PR, PIERZYNSKI GM, WHITNEY DA AND LAMOND RE. 1997. Long term effects of tillage and nitrogen source, rate, and placement on grain sorghum production. J Prod Agric 10: 141-146.

MOHAMMADI GR AND AMIRI F. 2011. Critical period of weed control in soybean (Glycine max) as influenced by starter fertilizer. Aust J Crop Sci 5: 1350-1355.

REICOSKY DC AND ALLMARAS RR. 2003. Advances in tillage research in North American cropping systems. J Crop Prod 8: 75-125.

SAS VERSION 9.1.3. 2004. SAS Institute. Cary, NC, USA.

Silva AF, FERrEIRA EA, CONCENÇO G, FERrEIRA FA, AspiazU I, Galon L, SEDIYAMA T AND Silva AA. 2008. Densidades de plantas daninhas e épocas de controle sobre os componentes de produção da soja. Planta Daninha 26(1): 65-71.

SOSNOSKIE LM, HERMS CP AND CARDINA J. 2006. Weed seed bank community composition in a 35 -yr-old tillage and rotation experiment. Weed Sci 54: 263-273.

TARKALSON DD, HERGERT GW AND CASSMAN KG. 2006. Long-term effects of tillage on soil chemical properties and grain yields of a dry land winter wheat sorghum/cornfallow rotation in the Great Plains. Agron J 98: 26-33. 